\title{
STRUCTURE AND SUSTAINABILITY OF SACRAMENTO'S URBAN FOREST
}

\author{
by E. Gregory McPherson
}

\begin{abstract}
The urban forest of Sacramento County, California, contains approximately 6 million trees. Tree density and basal area decrease along an urban-rural gradient from city ( 73 trees/ha, $13.4 \mathrm{~m}^{2} / \mathrm{ha}$ ), to suburban (64 trees/ha, $4.5 \mathrm{~m}^{2} / \mathrm{ha}$ ), to rural ( 10 trees $/ \mathrm{ha}, 0.9 \mathrm{~m}^{2} / \mathrm{ha}$ ) sectors. Within the city and suburban sectors, where $90 \%$ of all residents live, approximately $75 \%$ of total tree numbers, basal area, and leaf area occurs on residential land. Sacramento's urban forest is relatively sustainable. Seventy percent of the trees are in excellent or good condition, the population is well distributed by age and species, and the most abundant species are reasonably well suited to local conditions. Factors likely to trigger change in Sacramento's urban forest during the next 50 years are described (e.g., water conservation, development patterns, landscape maintenance issues) and species with potential to thrive in these conditions are listed for future planting and evaluation. A comparison of canopy cover, density, and basal area of trees in the city sectors of Sacramento and Chicago, Illinois, reveal surprising similarities. However, in Sacramento these values decrease along the urban-rural gradient, while in Chicago they increase. As human influences wane along the gradient, such factors as climate, soils, competition, and natural regeneration become more important forces in causing urban forest structure to approach presettlement conditions.
\end{abstract}

Keywords: Urban forest development; urban ecology; urban ecosystem

Urban and community forests are windows into the souls of our cities. They reflect the values, lifestyle preferences, and aspirations of current and past residents. By understanding a city's vegetation resource, we can better understand to what degree and how private and public institutions wish to invest in the future. Also, understanding an urban forest's structure is prerequisite to quantifying its function and value. "Structure" refers to the way vegetation is arrayed in relation to such other objects as buildings (Rowntree 1984). Quantifying current tree canopy cover, tree health, and the potential for additional canopy cover provides a basis for estimating impacts of community forestry programs on the future economic and environmental vitality of our cities.

In the Sacramento Urban Forest Ecosystem Study (SUFES), methods developed and applied in the Chicago Urban Forest Climate Project (CUFCP) are extended to a region with very different physical, social, and cultural features. As in Chicago, the goal of this study is to better understand relations between greenspace structure, function, and value by quantifying and comparing data across land uses and along the urban-to-rural gradient (McDonnell et al. 1993). The objectives of this paper are to: 1) describe the current structure of Sacramento's urban forest, 2) assess its long-term sustainability, and 3) compare selected structural traits of the urban forests of Sacramento and Chicago.

\section{Background}

Street trees have been the focus of most studies of urban forest structure and function. However, street trees represent only a small percentage of the total number of trees in cities, reportedly about $10 \%$ (Sampson et al. 1992). To assess sustainability of the entire urban forest and manage it accordingly, information on the total tree population is required. Few ground-based studies exist of urban forest structure for entire cities. A Los Angeles study presented data on leaf biomass and biogenic volatile organic compounds (BVOC) for subsequent air quality modeling (Horie et al. 1991). A study of Oakland described current forest structure, functional effects, and compensatory value (Nowak 1993a). The Chicago Urban Forest Climate Project (CUFCP) chronicled historic development of the region's urban forest (McPherson et al. 1993, 1994) and compared structural characteristics across three sectors reflecting the gradient of conditions from city to suburb to rural land (Nowak 1994).

Similarly, several studies have been conducted of the change in street tree populations over time (Richards 1982/83; Dawson and Khawaja 1985; Nowak et al, 1990; Polanin 1991) but few have described the entire landscape's transition from presettlement structure to urban forest. The influence of presettlement forest structure on the development of urban forests in Menlo Park and South Lake Tahoe, California, was studied by examining historic documents and relict trees in field plots (McBride and Jacobs 1986). Archival records and aerial photographs were used to describe landscape change in Tucson, Arizona (McPherson and Haip 1989), and Oakland, California (Nowak 1993b). Sample plots established during 1980 in residential neighborhoods of Bowling Green, Ohio, and Lincoln, Nebraska, were remeasured 
in 1992 to record change over a 12-year interval (Kielbaso et al. 1993). Perhaps because trees are the largest and most dominant component of the plant world in cities, these studies focused on them rather than on shrubs, grasses, and other herbs.

Urban forest sustainability. Sustainable urban forests are defined by Clark et al. (1997) as "the naturally occurring and planted trees in cities which are managed to provide the inhabitants with a continuing level of economic, social, environmental, and ecological benefits today and into the future." The authors' model recognizes that sustainaæble urban forests require a healthy tree and forest resource, communitywide support, and a comprehensive management approach.

It is generally agreed that a sustainable urban forest will produce long-term net benefits associated with a relatively stable tree population and canopy cover (Miller 1997). A stable urban forest is resilient to such short-term stressors as insect and pest attacks, cold, drought, and certain human impacts. Characteristics of an unsustainable forest include a declining population, many diseased trees, and rapid turnover that result in fluctuating tree numbers and a loss of economic, social, ecological, and aesthetic benefits. Rapid changes in the tree population, such as occurred when Dutch elm disease decimated large numbers of street trees due to monocultures, make it difficult to budget funds for urban forest management and can result in unexpectedly large expenditures over a short period of time.

Features of a sustainable forest resource component include adequate species and age diversity, a large percentage of healthy trees that are well adapted to local growing conditions, and climateappropriate tree cover with native forest stands as one component of overall canopy cover. A diverse mix of species is one feature of sustainable forests, and a common prescription is that no single species accounts for more than $5 \%$ to $10 \%$ of the entire population (Barker 1975; Miller and Miller 1991). However, Richards (1993) notes that stability of street tree populations is characterized by the extent to which species are adapted to the diversity of conditions that occur, rather than simply the number of species present. Good age diversity, to provide successful replacements, also is essential for long-term stability. For Syracuse, New York, street trees, Richards (1982/83) states that a good age distribution is $40 \%$ of trees at less than $20 \mathrm{~cm}(8 \mathrm{in}$.) dbh, $30 \%$ at 20 to $40 \mathrm{~cm}$ ( 8 to $16 \mathrm{in}$.) dbh, $20 \%$ at 40 to $60 \mathrm{~cm}$ ( 16 to 24 in.) $\mathrm{dbh}$, and $10 \%$ older trees. Healthy trees contribute to stable forest cover because of lower morbidity and mortality rates than are found in less healthy populations (Miller 1997). At a regional scale, Clark et al. (1997) identify climate-appropriate tree cover and preservation of native forest stands as two additional criteria for assessing sustainability. Frequently, local tree conservation ordinances specify canopy retention standards for wooded areas (Duerksen and Richman 1993).

Study area. The study area is Sacramento County, California $\left(2,578 \mathrm{~km}^{2}\right.$ [995 $\left.\left.\mathrm{mi}^{2}\right]\right)$, which lies in the Sacramento Valley bounded by the coastal mountain range $50 \mathrm{~km}$ ( $30 \mathrm{mi}$ ) to the west and the Sierra Nevada range to the east (Figure 1). The county is made up of three distinct regions. The Sierra Nevada foothills are along the northeast edge of the county and make up $6 \%$ of the study area. The foothills are undulating to hilly, and they slope down from elevations of $250 \mathrm{~m}(820 \mathrm{ft})$ to nearly sea level at the Sacramento River. The lower Sacramento Valley makes up $83 \%$ of the study area and extends through the western and central parts of the county (Tugel 1993). Elevation ranges from about $125 \mathrm{~m}$ (410 $\mathrm{ft}$ ) in the eastern part to nearly sea level along the Sacramento River in the southwestern part. Landforms in the lower Sacramento Valley include flood plains along the Sacramento, American, and Consumnes rivers and smaller creeks. Floodplain deposits are moderately to highly permeable deep, rich, sandy loams. Remnant basin landforms consist of unconsolidated clay with very low permeability and occur north of the American River and east of the Sacramento River deposits.

The most extensive area in the lower Sacramento Valley is the main valley floor, which extends through the central part of the county from the northern to southern boundary. The valley floor consists of low terraces, basin rims, and local basins with slopes of less than $1 \%$. Soils are a complex mixture of sediments, some having developed a hardpan layer near the surface that decreases rainwater percolation. The Sacramento-San Joaquin Delta is in the southwestern corner of the area and makes up $11 \%$ of the county. Much of the area is at or below sea level and has been protected from flooding by levees (Tugel 1993).

The climate is Mediterranean, characterized by hot, dry summers and cool, rainy winters. The growing season in Sacramento averages 282 days (base $0^{\circ} \mathrm{C}$ ). In Sacramento, the average annual temperature is $16.4^{\circ} \mathrm{C}\left(61.6^{\circ} \mathrm{F}\right)$, and the highest and lowest temperatures ever recorded are $45^{\circ} \mathrm{C}\left(114^{\circ} \mathrm{F}\right)$ and $8.3^{\circ} \mathrm{C}\left(17^{\circ} \mathrm{F}\right)$, respectively. Although average annual rainfall in Sacramento is $465 \mathrm{~mm}$ (18.3 in.), only about $1 \%$ occurs in June, July, and August. Because of the low humidity, evapotranspiration is high during the growing season and most landscapes are irrigated. The annual irrigation water requirement for a typical Sacramento lawn is $1,170 \mathrm{~mm}$ (46 in.). 


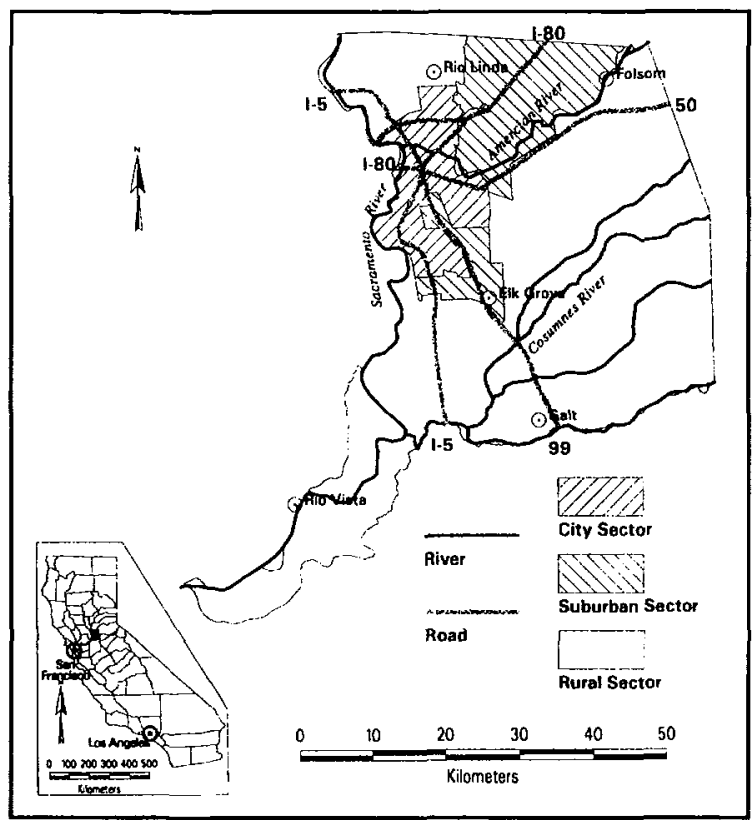

Figure 1. The Sacramento Urban Forest Ecosystem study site is located in California's Central Valley.

Before Anglo settlement, grassland communities covered much of Sacramento County. Two types of forest communities were present: blue oak woodland and riparian forest (Wolfe Mason Associates 1992). The blue oak woodland occupied upland areas and was characterized by sparse to dense stands of blue oak (Quercus douglasii) with interior live oak $(Q$. wislizenii) and foothill pine (Pinus sabiniana) interspersed. Shrubs and an annual grassland understory were often present. Relict blue oak woodlands occurred as scattered patches along the American River and more extensively along the Sierra Nevada foothills.

Riparian forests extended in several mile-wide bands along river courses and associated bottom lands. Early successional communities were dominated by willow (Salix spp.) and Fremont cottonwood (Populus fremonti), while trees such as Oregon ash (Fraxinus latifolia), California black walnut (Juglans hindsii), western sycamore (Platanus racemosa), and valley oak ( $Q$. lobata) were present in later-stage forests. Valley-oak-dominated forests are located in less hydric areas at a distance from main channels. Nearly impenetrable understories of shrubs, vines, and herbaceous plants harbored abundant populations of wildlife. In 1980, Sacramento County contained 4,620 ha $(11,413 \mathrm{ac})$ of woody riparian habitat (Katibah 1984), the most significant being approximately 2,000 ha $(5,000 \mathrm{ac})$ stretching the $14 \mathrm{~km}(23 \mathrm{mi})$ length of the lower American River. This parkway contains California's largest contiguous riparian forest that is surrounded by urban development (Wolfe Mason Associates 1992).

Anglo settlement first occurred within the 1,000 ha (4 $\left.\mathrm{mi}^{2}\right)$ Sutter grant located southeast of the confluence of the Sacramento and American rivers. During the first half of the 20th century, levee improvements encouraged growth south along the Sacramento River and east along the American River. The Sacramento River was and remains a natural obstacle to westward development. Following World War II, suburban growth expanded urban boundaries in all directions except west. In particular, suburban growth followed a corridor extending northeast from the old city into the Sierra and bounded by Interstate- 80 to the north and State Highway 50 to the south. Today, $90 \%$ of the county's 1.13 million population lives in metropolitan Sacramento, defined here as the city and suburban sectors.

\section{Methods}

This section describes sampling procedures and statistical analyses. Also, techniques used to estimate leaf surface area and to assess urban forest sustainability are detailed.

Sampling units. Sacramento County was subdivided into 71 SubRADs (Sub-Regional Assessment Districts), with SubRAD boundaries following census block group boundaries (SACOG 1995). Variation along an urban-rural gradient (a theoretical transect extending from city center to exurban areas) was depicted by subdividing the study area into three sectors: 1) the city sector-approximately congruent with city of Sacramento limits and containing 23,597 ha and 394,000 people, 2) the suburban sector-SubRADs outside the city with an average population density of $\geq 7.4$ persons per ha $(3 / \mathrm{ac})(37,142$ ha, 609,000 population), and 3) the rural sector-SubRADs outside the city with an average population density of $<7.4$ persons per ha (3/ac) $(197,086$ ha, 128,000 population).

Aerial photo sampling. Land use and land cover were interpreted from black-and-white aerial photographs as the first step of a two-stage sampling process. Within each SubRAD, land-use and land-cover types were analyzed by locating a minimum of 300 grid dots on aerial photographs and classifying each dot (Table 1). A sample of this size guarantees an accuracy within $5 \%$ of an assumed $30 \%$ mean tree cover with a $95 \%$ confidence. Three sets of aerial photographs were used in the analysis: $1993-1: 1,200$ black-and-white prints for Sacramento city SubRADs; 1989 to $1993-1: 2,400$ black-and-white prints for suburban sector SubRADs and some rural sector SubRADs; and 1:12,000, $23 \times 23 \mathrm{~cm}(9 \times 9 \mathrm{in}$.) blackand-white transparencies for rural sector SubRADs when 1:2,400 imagery was unavailable. 
The sample mean land cover percentage estimate $C$ for land cover type / in SubRAD $r$ and its standard error (se) estimate are given as

$$
\begin{aligned}
& C_{r l}=\frac{\text { DOTS }_{r l}}{\text { DOTS }_{r}} \times 100 \\
& \operatorname{se}\left(C_{r l}\right)=\sqrt{C_{r l} \times \frac{100-C_{r l}}{\text { DOTS }_{r}}}
\end{aligned}
$$

where

$$
\begin{aligned}
& \text { DOTS } S_{r}=\text { total number of dots in SubRAD } r \\
& \text { DOTS }_{r}=\text { number of dots interpreted as land } \\
& \text { cover type / of sampled DOTS in SubRAD } r .
\end{aligned}
$$

Proportions of different cover types were used to calculate available growing space (AGS) and canopy stocking level (CSL). AGS is the sum of tree/shrub and grass/soil cover. AGS reflects the proportion of land that is not covered with buildings, paving, and water, and thus readily available for tree planting. CSL is defined as the percentage of AGS covered by trees (i.e., the ratio of tree cover to AGS). CSL reflects the degree to which AGS has been filled (Rowntree 1984; McPherson and Rowntree 1989). Areas with low CSL indicate relatively high tree-planting potential. CSL is only an indicator of planting potential because areas with low CSL may not be suitable for trees due to other incompatible uses (e.g., ball fields, putting greens).

Ground sampling of vegetation. Vegetation and other surface data were collected on 675 randomly located $10 \times 10 \mathrm{~m}[33 \times 33 \mathrm{ft}]$ plots established as a sample of grid points from the aerial photographs (244 in the city sector, 214 in the suburban sector, 217 in the rural sector). Because this study's focus was on trees as the dominant element of vegetation within the urban ecosystem, the number of sample plots allocated to each land-use type was proportional to the estimated tree cover in the land use. Ground sampling was conducted during weekends as well as on weekdays to increase the likelihood of finding residents at home. If residents were not home, a letter was left explaining the study and requesting an appointment. If residents did not reply, crews returned to the site one additional time seeking permission to sample vegetation. Data were collected at $75 \%$ of the 900 samples drawn. A relatively uniform spatial distribution of nonrespondents suggests little bias in estimates due to the omission of samples.

Each $100-\mathrm{m}^{2}$ plot was centered on the dot shown on the aerial photograph. Land-use and land-cover information were recorded. Information was collected on 445 trees and shrubs that were growing in tree form (i.e., greater than $2 \mathrm{~m}$ [6.6 ft] tall, open-grown, tree-like form). The data included species, trunk dbh (at $1.4 \mathrm{~m}$ [4.6 ft]), crown radius, total tree height, height to base of crown, crown shape, percentage of crown occupied by leaves, percentage of leaves without discoloration or other visible damage, location, and condition. Tree location and condition percentages were based on criteria used in the CUFCP study (Nowak 1994).

Because the random sample was done proportional to tree cover based on aerial-photo-interpreted land use, to estimate tree numbers it was first necessary to account for differences between land use interpreted by the sampler on the ground and land use determined on the aerial photo for the same dot. The formulas for estimating the total number of trees and the standard error (se) for photo-land use / belonging to true-land use $k$ for a SubRAD $r$ are given in Appendix $A$ at the end of this article. To estimate the number of trees in a SubRAD by true-land use, it is assumed that tree cover characteristics are uniform for the same land use within a sector. Formulas for estimating the number of trees $\left(R y_{r k}\right)$ in SubRAD $r$ for true-land use $k$ and its standard error (se) are given in Appendix $B$ at the end of this article.

Estimating leaf area and basal area. The extent to which trees intercept pollutants and rainfall, shade buildings, and cool the air via evapotranspiration depends on the magnitude of leaf surface area. In this study, leaf surface area is estimated for each tree sampled in the field using allometric equations. The

\begin{tabular}{|c|c|}
\hline Land use & Description \\
\hline $\begin{array}{l}\text { Residential } \\
\text { Low-density } \\
\text { High-density }\end{array}$ & $\begin{array}{l}\text { dwellings } \\
1 \text { to } 3 \text { families (per structure) } \\
\geq 4 \text { families (per structure) }\end{array}$ \\
\hline Commercial/industrial & $\begin{array}{l}\text { small shops, malls, warehouses, } \\
\text { industry }\end{array}$ \\
\hline Institutional & $\begin{array}{l}\text { parks, hospitals, city buildings } \\
\text { schools, golf courses, cemeteries }\end{array}$ \\
\hline Transportation & $\begin{array}{l}\text { limited access highways, free- } \\
\text { ways, railroads, airports }\end{array}$ \\
\hline Agriculture & $\begin{array}{l}\text { land in crop production or } \\
\text { animal husbandry }\end{array}$ \\
\hline Vacant/wild & $\begin{array}{l}\text { apparently unmanaged and } \\
\text { unused land }\end{array}$ \\
\hline Land cover & Description \\
\hline Tree/shrub & woody vegetation \\
\hline Ground cover/soil & $\begin{array}{l}\text { bare soil, grass, and other } \\
\text { herbaceous plants }\end{array}$ \\
\hline Building & $\begin{array}{l}\text { permanent and temporary } \\
\text { structures }\end{array}$ \\
\hline Paving & streets, parking lots, sidewalks, etc. \\
\hline Water & lakes, rivers, ponds, pools, etc. \\
\hline
\end{tabular}
statistical approach outlined above was applied to infer results from the ground samples to each SubRAD.

Table 1. Land use and land cover type descriptions used in aerial photo interpretation. 
Following the procedures applied in the CUFCP (Nowak 1994), estimates of leaf area for broadleaf deciduous and evergreen trees were based on two regression formulas derived from leaf samples from 54 park trees in Chicago. One regression $\left(r^{2}=0.91\right)$ incorporated a shading coefficient for species with known crown density. Crown height and diameter were the only parameters used in the second equation $\left(r^{2}=\right.$ 0.86 ). A volumetric approach was used for conifers, palms, and broadleaf trees with dimensions outside the range suitable for regression. Crown volume was calculated based on measured height, diameter, and shape. Foliar biomass factors $\left(\mathrm{g} / \mathrm{m}^{3}\right)$ were applied to the crown volume to estimate foliar dry weight based on measured data and information from the literature. Areal biomass factors $\left(\mathrm{g} / \mathrm{m}^{2}\right)$ were then applied to calculate leaf surface area for each sample tree. To account for effects of defoliation on leaf surface area, crown condition adjustment factors were applied. Total tree leaf area within true-land use $k$ in SubRAD $r$ was divided by total area of land use $k$ in SubRAD $r$ to derive leaf area density $\left(\mathrm{m}^{2} / \mathrm{m}^{2}\right)$.

Basal area, or land area covered by tree stems $\left(\mathrm{m}^{2} / \mathrm{ha}\right)$, is a better indicator of tree dominance than tree density because it incorporates both size and number. Basal area was calculated from measurements of trunk diameter at breast height.

Assessing sustainability. Four indicators were analyzed to assess sustainability of the region's urban forest: species diversity, size diversity, condition, and species suitability. These indicators were evaluated for the city, suburban, and rural sectors, and several were applied to the city of Sacramento street tree population. SUFES data relied on samples of street and off-street trees, while Sacramento street tree data were based on results of a complete street tree inventory conducted by field crews from 1976 to 1983 .

To assess species diversity, the number of tree species sampled is reported and the distribution of individuals among species and genera (i.e., evenness of distribution) is calculated by sector. Because of difficulty identifying among species of certain genera (e.g., Prunus) and cultivars of certain species (e.g., London plane [Platanus acerifolia] and Callery pear [Pyrus calleryana 'Bradford']), species richness and a species diversity index value were not calculated. To assess size diversity and condition, sample data were stratified according to $\mathrm{dbh}$ and condition classes, respectively.

A two-step process was used to rate the relative suitability of tree species to conditions existing in Sacramento. The most common species were ranked on a scale of 1 to 3 ( 3 being most suitable) for 13 suitability factors. To limit subjective evaluation, data from three computerized tree selection programs were used to rank suitability (Pacific Gas \& Electric 1994; Gilman et al. 1996; Reimer 1997). Next, each of the 13 suitability factors was weighted 1,3 , or 5 , depending on an arbitrary evaluation of their relative importance (Table 2). Scores were totaled for each species and divided by the total number of factors to derive an average score. Suitability factors were selected to include biological adaptation (i.e., pest and disease resistance, soil tolerance, climate adaptation, drought tolerance, longevity, ozone tolerance, cultivar availability) and tree management needs (i.e., tidiness, pruning needs, wood strength, pavement problems). Also, several factors address human health issues (i.e., pollen production and emissions of BVOC that influence ozone formation). Because tree species planted now influence the future sustainability of Sacramento's urban forest, sales information was obtained from two local nurseries and the Sacramento Tree Foundation.

\section{Results}

Land use and tree cover. In the city and suburban sectors, residential land uses represent $42 \%$ and $50 \%$ of total land use, respectively (Figure 2). Of these residential lands, approximately $90 \%$ contain low-density housing ( 1 to 3 units per structure). Land interpreted from aerial photos as vacant/wild accounts for about $20 \%$ of city and suburban lands and $41 \%$ of land in the rural sector. As expected, percentages of land in commercial/industrial, institutional, and transportation land uses decrease along the urban-rural gradient. For example, percentages of commercial lands average $15 \%, 11 \%$, and $2 \%$ of all land in urban, suburban, and rural sectors, respectively. Agricultural uses occupy $47 \%$ of the rural sector land.

Tree canopy cover is $13 \%$ and $15 \%$ of land in the city and suburban sectors, but only $5 \%$ of rural sector land. City and suburban tree cover values compare favorably with values of $9 \%$ (Myrup and Morgan 1972) and $14 \%$ (Rowntree et al. in press) reported for the urbanized region in earlier studies. In the city and suburban sectors, tree and grass/soil cover comprise about half of the low-density residential land (Figure 2). Approximately $40 \%$ of these pervious surfaces is tree/shrub cover and the remainder is grass/soil cover. Impervious surface cover (buildings and paving), which is related to stormwater runoff and watershed health, is $68 \%$ of the high-density residential land and $75 \%$ of the commercial/industrial land in the city and suburban sectors. These percentages are consistent with impervious surface cover values found for similar land uses in other cities (Arnold and Gibbons 1996). Grass/ soil is the predominant surface cover in institutional and vacant/wild lands, accounting for $88 \%$ of all land cover in the rural sector. 
Canopy stocking levels (CSL) are relatively high for the residential and commercial/industrial land uses in the city sector, indicating limited greenspace is available for new plantings (Table 3). Lower values for the suburban sector suggest relatively greater planting potential in these areas. One exception is suburban institutional land, which has a CSL of $35 \%$ compared to the city value of $27 \%$. This relatively high value may be due to the savanna-like character of most parks, schools, and cemeteries in the city. By comparison, many of the institutional lands in the suburban sector contain natural oak woodlands and heavily treed riparian plant communities.

The distribution of tree canopy cover across the landscape reflects land development patterns. Treecover percentages are relatively low in rural SubRADs with predominantly agricultural land use, as well as in the Sacramento core commercial area (Figure 3). Tree cover is greatest in areas extending south and northeast from the city center. One corridor runs south following the Sacramento River and Interstate 5. A second corridor extends northeast through progressively more recent suburban development to the Folsom area.

Tree numbers, basal area, and leaf area. There are approximately 6 million trees in Sacramento County (se 639,000). The largest number of trees is located in the suburban sector (39\%), followed by the rural $(32 \%)$ and city (29\%) sectors (Table 3$)$. However, on average, tree density is greater in the city $(73 / \mathrm{ha})$ than in the suburban (64/ha) and rural (10/ha) sectors. Low-density residential land uses contain the greatest number of trees per unit land area, with mean densities of 138 and 83 trees per ha in the city and suburban sectors, respectively. Similar tree densities were reported for residential areas in Bowling Green, Ohio (113/ha), and Lincoln, Nebraska (72/ha) (Kielbaso et al. 1993).

There are approximately 4 trees per capita in the city and suburban sectors and 15 trees per capita in the rural sector. Assuming a total of 115,000 street trees in the city of Sacramento (Wolfe Mason Associates 1992), there are 0.3 street trees per capita and 14 off-street trees for each street tree in Sacramento. A mean of 0.37 trees per capita was reported for a survey of 22 U.S. street tree populations (McPherson and Rowntree 1989). Adding 35,000 park trees to Sacramento's street tree population brings the number of publicly managed trees to 0.38 per capita. This number exceeds the median value for California cities of 0.24 (Bernhardt and Swiecki 1993) as well as the national mean of 0.33 for cities with populations between 250,000 and 500,000 (Tschantz and Sacamano 1994).
Although the city sector contains only $11 \%$ of total land in the county, it contains $48 \%$ of total basal area. This can be explained by its high tree densities and many large, old shade trees. The remaining basal area is distributed nearly equally between the suburban and rural sectors. Basal area densities are greatest in residential land uses (Table 3). Intermediate densities occur in institutional and vacant/wild lands ( 1 to $5 \mathrm{~m}^{2} / \mathrm{ha}$ ). Basal areas calculated from data reported for residential areas in Bowling Green, Ohio (5.9 m²/ha), and Lincoln, Nebraska (6.2 $\mathrm{m}^{2} / \mathrm{ha}$ ), (Kielbaso et al. 1993) are similar to those for low-density residential land in the suburban sector of Sacramento $\left(5.9 \mathrm{~m}^{2} / \mathrm{ha}\right)$, but substantially less than found in the city sector $\left(24.4 \mathrm{~m}^{2} / \mathrm{ha}\right)$.

Despite the relatively large amount of total basal area in the city sector, the greatest percentages of total tree leaf area occur in the suburban (43\%) and rural (38\%) sectors. One possible explanation for this relates to species distribution and their leaf area indexes. Trees in the city are chiefly broadleaf deciduous species with leaf area indexes (LAl is the ratio of leaf surface area to ground area under the tree dripline) typically ranging from 3 to 6 . Oaks and other broadleaf evergreens, as well as conifers, are relatively more abundant in the suburban and rural sectors, especially in the vacant/wild and institutional land uses. Their LAls typically range from 6 to 11. Leaf area densities (tree leaf area per unit land area) range from 2 to 3 in city and suburban sector residential lands and suburban vacant/wild lands (Table 3). The difference in species mix may also explain why the leaf area density for vacant/wild land in the suburban sector is $2.4 \mathrm{com}$ pared to 0.2 in the city, despite similar basal area densities (Table 3).

Assessing indicators of sustainability. In this section the following four indicators of sustainability are assessed: species diversity, age diversity, condition, and suitability.

Species diversity. A total of 118 species of trees was identified, a relatively rich assemblage of tree species in Sacramento County. Individual trees are most evenly distributed among species and genera in the city and suburban sectors, and least in the rural sector and for street trees in the city of Sacramento (Table 4). Eight tree species account for $69 \%$ of all street trees in the city of Sacramento. The two most common species, Modesto ash (Fraxinus velutina 'Modesto') and the American sycamore (Platanus occidentalis), require frequent attention to control pest and disease problems. Increased planting of other welladapted species is needed to increase population stability and long-term health of the municipal forest resource. 
In the city sector, the most abundant 8 genera account for only $44 \%$ of all street and off-street trees. In older areas, the large-growing shade trees (elm [Uimus spp.] and hackberry [Celtis spp.]) coexist with smaller "understory" species (i.e., flowering cherry [Prunus spp.], juniper [Juniperus spp.], birch [Betula spp.], camellia [Camellia spp.], dogwood [Cornus spp.]). Large palms (e.g., Phoenix spp., Washingtonia spp.) are visually important reminders of Sacramento's transformation from an unshaded and insufferably hot city to a balmy destination spot. Pines (Pinus spp.) and coast redwood (Sequoia sempervirens) are common in more recently developed areas.

Relict native interior, blue, and valley oaks (Quercus wislizenii, douglasii, and lobata) still exist among encroaching development in the Sierra foothills and riparian corridors of the suburban sector. Trees within developed areas reflect a shift in preference from largegrowing shade trees, such as elms and sycamores, to smaller-stature trees (e.g., mulberry [Morus spp.], sweetgum [Liquidamber styraciflua] and flowering cherry) (McPherson and Rowntree 1989). The trend towards more compact developments with smaller lots and the need for evergreen plants as privacy buffers may account for the abundance of coast redwood, Italian cypress (Cupressus sempervirens 'Stricta'), and pine.

Based on this sample, the top 8 genera account for $96 \%$ of all trees in the rural sector. Native trees such as oak and foothill pine are mixed with hardy shade trees such as silk tree (Albizia julibrissin), Russian olive (Elaeagnus angustifolia), sweetgum, and mulberry. Old favorites such as privet and eucalypt (Ligustrum spp. and Eucalyptus spp.) occur in farmsteads; the latter are found along rural roadsides and as windbreaks.

Age diversity. When compared to the "ideal" distribution of trees by stem size (Richards 1982/83) assuming that most of the small-stemmed trees are young - it appears that the city of Sacramento's street tree population needs more replacements (only $33 \%$ are 0 to $15 \mathrm{~cm}$ [0 to $6 \mathrm{in}$.] dbh) (Figure 4). Nearly 50\% of city street trees are in their early functional period (16 to $46 \mathrm{~cm}$ [6.3 to $18 \mathrm{in}$.] dbh), suggesting that tree planting 10 to 25 years ago has resulted in many established trees that promise future benefits. Although only $2 \%$ are mature trees with most of their functional life behind them ( $\geq 77 \mathrm{~cm}[30 \mathrm{in}]$.$) , many are elm, ash,$ and sycamore species that require intensive maintenance to suppress pest and disease problems.

Nearly $50 \%$ of all trees in the city sector are small sized and probably relatively young. Many of these trees are residential yard tree replacements and trees in wooded parklands, such as the American River Parkway. This preponderance of small trees provides insurance against the loss of future benefits due to the relatively high mortality of young trees.

The age diversity patterns for the suburban and rural sectors are similar to the pattern for city street trees. Compared to the "ideal," there is a deficit of small, young trees and a surplus of trees in the early, functional size class.

Condition. About $70 \%$ of the trees in Sacramento County are in good or excellent condition, $20 \%$ moderate, and $10 \%$ in poor, dead, or dying condition (Table 5 ). In the city and suburban sectors, where the vast majority of trees are on low-density residential lands, $83 \%$ and $86 \%$ are in good or excellent condition, respectively. In the rural sector, $55 \%$ of the trees are in vacant/wild lands, where they receive little or no maintenance. Therefore, it is not surprising that nearly $20 \%$ of rural sector trees are in poor condition or dead, versus $4 \%$ and $7 \%$ in the city and suburban sectors, respectively. Hence, the distribution of dead and dying trees tends to increase along the urban-rural gradient, while the percentage of trees in excellent condition decreases.

Suitability. The extent to which the most abundant tree species in each sector are well suited to growing

\section{Table 2. Descriptions and weightings of suitability factors.}

\begin{tabular}{lll} 
Suitability factor & Description & Weighting \\
\hline Disease/pest tolerance & affects management cost, tree health, longevity \\
Soil tolerance and drainage & tolerance to textures and drainage affect health & 5 \\
Tidiness & litter and weediness influence maintenance costs & 5 \\
Climate adaptation & hardiness to climatic extremes affects tree health \\
Pruning needs & branching pattern/growth rate affect pruning costs \\
Wood strength & brittle wood makes trees susceptible to storm damage \\
Pavement damage & shallow roots heave paving \\
Drought tolerance & stress during periods of drought affects tree health \\
Cultivars available & provides options for better matching of tree to site \\
Longevity & genotypic trait affects replacement costs \\
Ozone tolerance & high smog levels affect tree health \\
BVOC emissions & influences smog levels and human health \\
Allergenicity & pollen production affects allergy sufferers \\
\hline
\end{tabular}




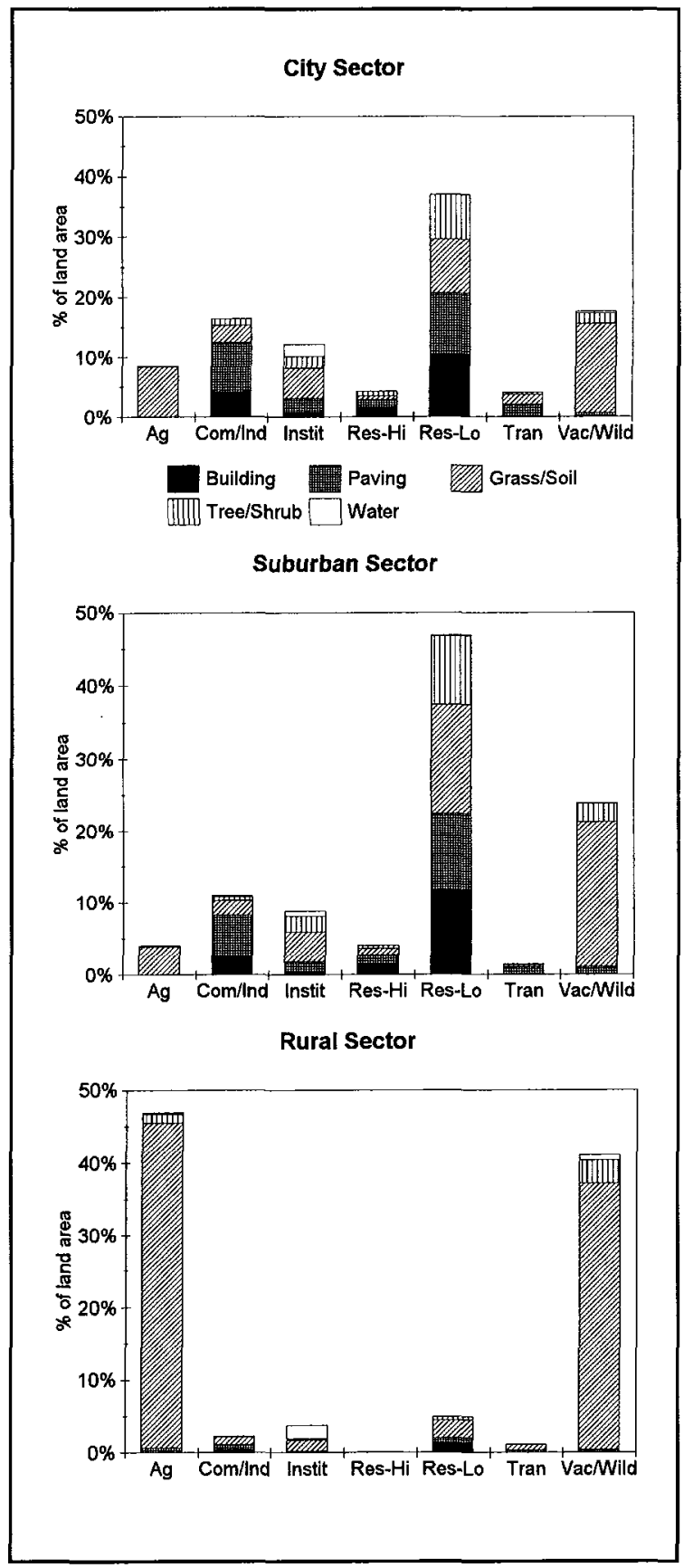

Figure 2. The distribution of land cover types and land uses varies across sectors. In the city and suburban sectors, tree/shrub cover is primarily located in residential land uses. Land use types are agriculture, commercial/industrial, residential-high density, residential-low density, transportation, and vacant/wild. conditions, management issues, and policy concerns is indicated by their average suitability scores (Table $6)$. The average score for the top 8 species in the suburban sector (6.8) is slightly lower than scores for the other sectors and the list of currently planted species (7.0 to 7.1). The narrow range of scores is due in part to the narrow range of rankings ( 1 to 3 for each suitability factor). The lack of more detailed information in the computer databases (PG\&E 1994; Gilman et al. 1996; Reimer 1997) makes it difficult to expand this range.

In the city sector, 3 species have average scores greater than 8.0 (camellia, lacebark elm [UImus parvifolia], Chinese pistache [Pistacia chinensis]) and two species score below 6.0 (European white birch [Betula pendula] and Canary Island pine [Pinus canariensis]). No species scores above 8.0 in the suburban sector, while 2 score below 6.0 (mulberry and tree of heaven [Ailanthus altissima]) in that sector. In the rural sector, 1 species scores above (blue oak) and 1 scores below (Austrian pine [Pinus nigra]) the benchmarks of 8.0 and 6.0. Two species commonly planted today have average scores above 8.0 (Chinese pistache and sour gum [Nyssa sylvatica]) and none score below 6.0 .

Tree species with the highest average score are camellia, blue oak, lacebark elm, sour gum, Chinese pistache, and crape myrtle (Lagerstroemia indica). Under this evaluation scheme, the least suitable species are European white birch, mulberry, tree of heaven, Aus-

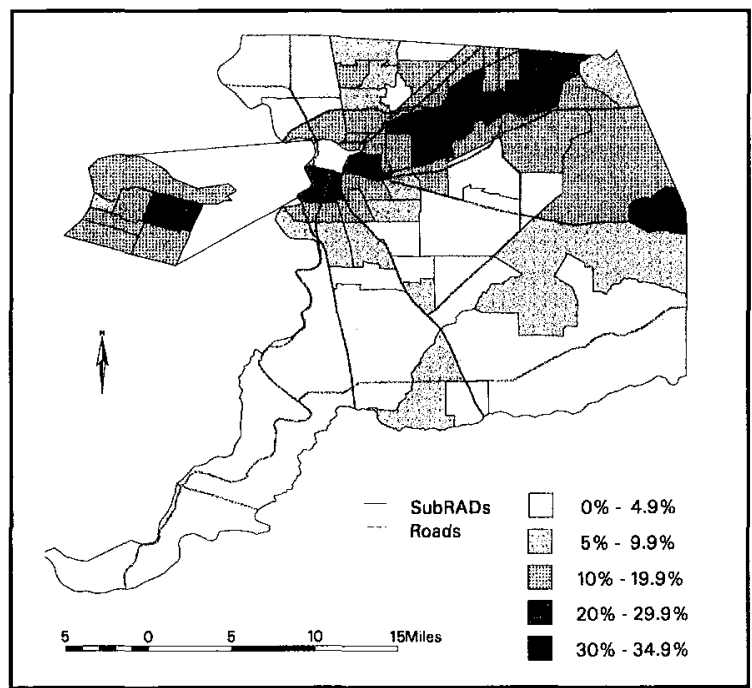

Figure 3. Tree canopy cover is primarily located in the northern part of the county, where urban development has occurred. 
Table 3. Structural information by sector and land use (standard errors are shown in parentheses).

\begin{tabular}{|c|c|c|c|c|c|c|c|c|}
\hline & Res.-Low & Res.-High & Com./Ind. & Institu. & Transport. & Agricul. & Vac./Wild & Totals \\
\hline \multicolumn{9}{|c|}{ Canopy stocking level (\%) } \\
\hline City & $45.0(0.5)$ & $46.6(1.7)$ & $26.7(0.9)$ & $27.0(0.6)$ & $16.9(0.0)$ & $1.1(0.3)$ & $10.2(0.3)$ & $23.4(2.0)$ \\
\hline Suburban & $38.3(0.3)$ & $37.2(1.3)$ & $20.1(0.8)$ & $35.3(0.5)$ & $10.3(1.5)$ & $5.6(0.3)$ & $11.5(0.2)$ & $25.1(0.1)$ \\
\hline Rural & $12.8(0.2)$ & $27.1(0.4)$ & $7.7(0.3)$ & $13.7(0.3)$ & $1.1(0.1)$ & $2.8(0.0)$ & $8.0(0.1)$ & $5.6(0.0)$ \\
\hline \multicolumn{9}{|c|}{ Tree numbers $(1,000 \mathrm{~s})$} \\
\hline City & $1,254(332)$ & $148(48)$ & $139(80)$ & $127(52)$ & $9(5)$ & $0(0)$ & $56(29)$ & $1,733(350)$ \\
\hline Suburban & $1,569(211)$ & $100(42)$ & $104(45)$ & $273(102)$ & $0(0)$ & $0(0)$ & $326(74)$ & $2,371(254)$ \\
\hline Rural & $423(92)$ & $0(0)$ & $243(196)$ & $198(137)$ & $0(0)$ & $0(0)$ & $1,074(395)$ & $1,939(471)$ \\
\hline \multicolumn{9}{|c|}{ Tree density (no./ha) } \\
\hline City & $138(36)$ & $117(38)$ & $42(24)$ & $34(14)$ & $6(4)$ & $0(0)$ & $26(13)$ & $73(15)$ \\
\hline Suburban & $83(11)$ & $44(18)$ & $27(12)$ & $47(18)$ & $0(0)$ & $0(0)$ & $63(14)$ & $64(7)$ \\
\hline Rural & $33(7)$ & $0(0)$ & $29(23)$ & $18(13)$ & $0(0)$ & $0(0)$ & $14(5)$ & $10(2)$ \\
\hline \multicolumn{9}{|c|}{ Basal area $\left(m^{2} / h a\right)$} \\
\hline City & $24.4(12.4)$ & $32(17.9)$ & $3.8(3.5)$ & $7.8(5)$ & $1.2(0.9)$ & $0.0(0.0)$ & $4.5(3.3)$ & $13.4(5)$ \\
\hline Suburban & $5.9(1.7)$ & $4.2(1.8)$ & $0.6(0.2)$ & $3.4(1.6)$ & $0.0(0.0)$ & $0.0(0.0)$ & $4.9(1.4)$ & $4.5(0.9)$ \\
\hline Rural & $1.3(0.4)$ & $0.0(0.0)$ & $0.4(0.4)$ & $2.9(2.0)$ & $0.0(0.0)$ & $0.0(0.0)$ & $1.6(0.6)$ & $0.9(0.3)$ \\
\hline \multicolumn{9}{|c|}{ Leaf area density $\left(m^{2} / m^{2}\right)^{\mathrm{b}}$} \\
\hline City & $2.1(0.7)$ & $3.1(1.1)$ & $0.2(0.2)$ & $0.7(0.5)$ & $0.1(0.1)$ & $0.0(0.0)$ & $0.2(0.2)$ & $1.1(0.3)$ \\
\hline Suburban & $2.0(0.5)$ & $2.0(1.1)$ & $0.2(0.2)$ & $0.9(0.4)$ & $0.0(0.0)$ & $0.0(0.0)$ & $2.4(1.0)$ & $1.7(0.3)$ \\
\hline Rural & $0.3(0.3)$ & $0.0(0.0)$ & $0.2(0.2)$ & $2.6(2.0)$ & $0.0(0.0)$ & $0.0(0.0)$ & $0.3(0.1)$ & $0.3(0.1)$ \\
\hline
\end{tabular}

${ }^{a}$ Canopy stocking level is the ratio of tree cover to available growing space (tree and grass/soil cover) and lower values indicate higher potential for additional tree planting.

beaf area density calculated as tree leaf surface area (1 side) per unit land area.

trian pine, Canary Island pine, Mexican fan palm (Washingtonia robusta), Callery pear, and red maple (Acer rubrum).

Overall, Sacramento's urban forest is relatively sustainable. Most trees are healthy, the population is well distributed by age and species, and the most abundant species are reasonably well adapted to local conditions.

\section{Discussion}

Influence of presettlement forest structure and management implications. McBride and Jacobs (1976) state that the transition of urban forests from presettlement to postsettlement condition is analogous to succession in natural forest communities. Using this analogy, the urban forest in the city of Sacramento is comparable to a climax type. It contains few relict trees from pre-urban days and is a diverse collection of tree species that reflect 150 years of changing horticultural preferences. The many large, old shade trees and complex understory provide climate modification, rich habitat for certain wildlife, and a relatively stable tree canopy cover. Although exact measures of presettlement tree density are unavailable for Sacramento, pre-urban tree densities were estimated as 4 per ha and 249 per ha for oak savanna and oak forest stands, respectively, in Menlo Park, California (McBride and Jacobs 1976). Sacramento city's postsettlement tree density (73/ha) and basal areas $\left(13 \mathrm{~m}^{2} / \mathrm{ha}\right.$ ) are probably much greater today than they were 150 years ago. However, during the past 50 years, tree density is likely to have declined, while basal area has increased. Storms, disease, and other stressors have culled the weakest trees, and the best-adapted individuals have grown larger. As the relatively high CSLs indicate (Table 3), tree planting is needed primarily to replace old trees rather than to increase canopy stocking levels. In central Sacramento, where large, old trees abound, it is not necessary to replace each tree that is removed because surrounding trees occupy most of the growing space. In such areas, careful management of mature trees and judicious replacement planting should make it possible to maintain a stable tree canopy cover.

In residential areas of Sacramento, the suburban forest's density and basal area are surprisingly similar to values reported for two midwestern cities that are less dependent on summer irrigation to maintain a healthy canopy cover. The difference between potential evapotranspiration and rainfall for the months May through October is $66 \mathrm{~cm}$ (26 in.) in Sacramento versus $30 \mathrm{~cm}$ (12 in.) in Lincoln, Nebraska, and $20 \mathrm{~cm}(8$ 
in.) in Bowling Green, Ohio (Toro Co. 1966). To overcome the natural limits to tree density and growth placed by the region's xeric summer climate, residents of Sacramento lavishly irrigate their landscapes.

Most development in the suburban sector has occurred during the past 40 years. Perhaps because of the past insect and disease problems and storm damage associated with the large shade trees in the city of Sacramento, this era is marked by a preference for smaller shade trees such as mulberry, flowering cherry, and Modesto ash. Also, preference for smaller-sized trees may be a response to land development patterns that have increased building densities and reduced space for planting of larger-sized trees on residential land. The typical longevity of many of these exotic suburban species is only 30 to 50 years. Now the first generation of tree replacement has begun. Assuming that the preference for smaller-sized trees continues, with time the suburban forest will be characterized by a higher density of smaller-stemmed trees and a relatively shorter rotation length than in the city forest. Hence, the suburban forest is analogous to a subclimax forest with a relatively rapid turnover rate. If well-adapted replacement trees are selected and continuously planted, this forest type can become relatively resilient to the biotic and abiotic stressors that can destabilize a forest.

Tree cover (5\%), density (10/ha), and basal area $\left(1 \mathrm{~m}^{2} /\right.$ ha) are lowest in the rural sector, where cropland, pasture, and wetlands exclude extensive forest cover. Although both urbanization and agriculture have radical impacts on ecosystem processes, the structure and species composition of the rural sector forest more closely approximates the region's preurban condition than does the forest of the Sacramento city sector. Tree cover is relatively sparse in the rural sector for three reasons. First, conversion of land to agricultural use is not accompanied by tree planting, as it is when converted to urban use. Second, summer drought limits tree establishment on unirrigated upland sites. Finally, wetlands throughout the Sacramento-San Joaquin Delta restrict tree establishment. Thus, arboreal vegetation in the rural sector is largely characterized by remnant patches and opportunistic individuals that survive where interstitial spaces occur in the agricultural/wildland matrix. Management of the vegetation resource should focus on conservation of threatened plant communities, such as the relict blue oak stands in the Sierra foothills and remnant riparian forests that occur along tributaries and rivers. Promoting biodiversity will allow residents to obtain multiple benefits from healthy ecosystems, including wildlife, recreational, and aesthetic values. A diverse assemblage of plant communities at the regional scale is an important aspect of overall urban forest health.

Comparison with the Chicago region urban forest. The concept of successional change reflected along a spatial gradient has application in Chicago as well as in Sacramento. Chicago tree density and basal area increase along the gradient from urban to rural (Table 7). In Sacramento, they decrease along the same gradient. In both cases, rural conditions begin to approximate those of the presettlement forests. Tree density and basal area in rural Chicago are 171 per ha and $19 \mathrm{~m}^{2}$ per ha compared to a mean of 442 per ha and $30 \mathrm{~m}^{2}$ per ha, respectively, for nearby beech-maple forests (Levenson 1981). In both regions, agriculture and urban development restrict tree cover. However, in Chicago's more suitable climate and soils, mildly disturbed rural areas support more extensive forest stands than in the more xeric Sacramento region.

Differences between vegetation structure in Chicago and Sacramento are accentuated as one moves out along the urban-to-rural gradient. Despite a popu-

Table 4. Percentage of total tree numbers for the most abundant genera and species (standard errors are shown in parentheses).

\begin{tabular}{|c|c|c|c|c|c|c|c|}
\hline \multicolumn{2}{|l|}{ City streets } & \multicolumn{2}{|c|}{ City sector } & \multicolumn{2}{|c|}{ Suburban sector } & \multicolumn{2}{|l|}{ Rural sector } \\
\hline Tree & $\%$ & Tree & $\%$ & Tree & $\%$ & Tree & $\%$ \\
\hline $\begin{array}{l}\text { Fraxinus velutina } \\
\text { 'Modesto' }\end{array}$ & 23.5 & Prunus spp. & $10.0(3.3)$ & Quercus spp. & $19.7(4.1)$ & Quercus spp. & $45.1(15.9)$ \\
\hline Platanus occidentalis & 11.2 & Juniperus spp. & $6.2(5.5)$ & Prunus spp. & $6.3(1.4)$ & Albizia julibrissin & $14.4(0.0)$ \\
\hline Zelkova serrata & 8.2 & UImus spp. & $5.5(3.4)$ & Celtis spp. & $6.1(2.6)$ & Pinus spp. & $11.4(5.6)$ \\
\hline $\begin{array}{l}\text { Liquidamber } \\
\text { styraciflua }\end{array}$ & 7.4 & Pinus spp. & $5.5(2.5)$ & Morus spp. & $5.4(3.6)$ & $\begin{array}{l}\text { Elaeagnus } \\
\text { angustifolia }\end{array}$ & $8.4(8.4)$ \\
\hline Platanus orientalis & 4.5 & Camellia spp. & $4.1(2.2)$ & Citrus spp. & $4.8(2.4)$ & Unidentified species & s $4.2(4.2)$ \\
\hline Pistacia chinensis & 4.4 & Celtis spp. & $3.9(2.2)$ & Cupressus spp. & $4.2(2.7)$ & Ligustrum spp. & $4.2(3.9)$ \\
\hline UImus procera & 3.6 & Cornus spp. & $3.8(3.3)$ & Pinus spp. & $2.8(1.3)$ & Eucalyptus spp. & $4.1(3.9)$ \\
\hline Top 8 total & 68.7 & & $43.9(25.6)$ & & $54.1(20.4)$ & & $96.0(45.4)$ \\
\hline
\end{tabular}




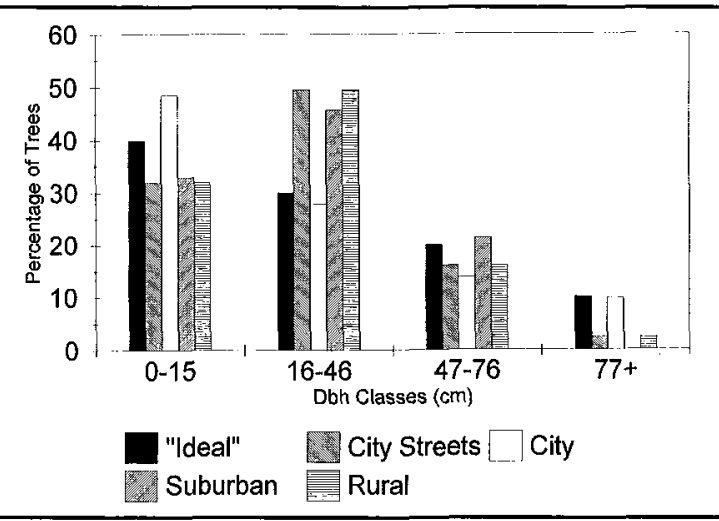

Figure 4. Age diversity is reflected by the distribution of trees by diameter class for each sector and the city of Sacramento street tree population. The "ideal" distribution is adapted from research on Syracuse street trees (Richards 1982/83). Dbh classes in inches: $0-6,6-18,18-30$, and $30+$.

lation density that is approximately three times that of Sacramento and considerably more impervious surface cover (60\% versus $42 \%)$, Chicago's tree cover, density, and basal area are similar to Sacramento's (Table 7). These comparable values for the city sectors in Chicago and Sacramento suggest that in their efforts to achieve desired levels of canopy cover in city centers, humans have an overarching influence on forest structure. People are the primary creators of planting space, stewards of vegetation, and agents of selection. Tree density and basal area are 2 to 3 times greater in suburban Chicago than suburban Sacramento, and about 20 times greater in rural Chicago than rural Sacramento. In part, this trend reflects the waning influence of humans on forest structure, the increasing influence of presettlement forest structure, and the greater importance of such nonanthropogenic processes as climate, soils, competition, and natural regeneration.

The number of trees per capita tends to be inversely related to population density in both Sacramento and Chicago (Table 7). Values of 3.9 and 4.4 for the suburban and city sectors in Sacramento match their comparable population densities. The sparse human population in Sacramento's rural sector accounts for its relatively high value of 15.2. In Chicago (city sector), there are only 1.5 trees per capita, but values increase to 13.7 and 19.1 , in suburban and rural Chicago, respectively. Increasing ratios along the urban-rural gradient are due to lower population densities, extensive forest preserves, and greater amounts of growing space.

In Sacramento's city sector, there are approximately 0.29 street trees per capita and a ratio of 14
Table 5. Tree condition as a percentage of sector population (standard errors are shown in parentheses).

\begin{tabular}{lrrrr}
\hline & Excellent $^{\mathrm{a}}$ & \multicolumn{1}{c}{ Good $^{\mathrm{b}}$} & Moderate $^{\mathrm{c}}$ & Poor/Dead $^{\mathrm{a}}$ \\
\hline City & $17.3(5.7)$ & $65.8(13.0)$ & $13.3(14.4)$ & $3.6(12.7)$ \\
Suburban & $12.8(3.9)$ & $72.7(7.9)$ & $7.4(1.9)$ & $7.2(1.8)$ \\
Rural & $10.7(4.6)$ & $26.4(10.6)$ & $43.5(16.6)$ & $19.4(4.2)$ \\
County & $13.4(2.7)$ & $55.9(5.9)$ & $20.7(20.7)$ & $10.1(1.6)$ \\
\hline
\end{tabular}

${ }^{a}<5 \%$ of crown shows dieback or leaf discoloration.

${ }^{5} 5-25 \%$ dieback or discoloration.

26-50\% dieback or discoloration.

d $>50 \%$ dieback or discoloration.

off-street trees for each street tree. Chicago's city sector contains 0.15 street trees per capita and nine offstreet trees for each street tree. The off-street to street tree ratio increases along the Chicago gradient to 36 and 76 in the suburban and rural sectors, respectively. These data suggest that adopting the common notion of 10 off-street trees for every street tree can lead to erroneous estimates of total tree numbers, with a tendency to underestimate numbers for cities with low population densities. Also, these findings confirm that street trees are relatively more frequent in densely populated cities than in suburban or rural areas. In the city of Chicago, street trees accounted for $10 \%$ of all trees and $25 \%$ of total tree leaf area (Nowak 1994). Because these street trees affect a relatively large number of city dwellers, their health and the benefits they confer are especially important.

Sustainability and tree selection. Tree selection at both the planting site and regional scale is critical to the future sustainability of Sacramento's urban forest. At the regional scale, it is important to create a diverse mix of species. While most of the forest should consist of species proven to be well adapted to local conditions, a small percentage should be untested trees that merit evaluation. The Sacramento Urban Forest Management Plan (Wolfe Mason Associates 1992) recommends that $5 \%$ of municipal plantings be "experimental" taxa. Those that prove adaptable can become a larger part of local tree planting and replacement programs.

At the planting site scale, it is important to select species and cultivars that best match requirements of the site and are appealing to those who will maintain them (Sommer et al. 1990). Careful selection is important because of high planting costs, negative public attitudes that develop from experiences residents have with ill-suited trees, and the long-term costs of maintaining problem trees.

Expanding Sacramento's tree palette is one means of increasing genotypic diversity and population stability. In developing a list of experimental trees, it is important to consider how changing development patterns, environmental conditions, and human pref- 
Table 6. Relative suitability of predominant tree species $(1=$ least suitable and $3=$ most suitable).

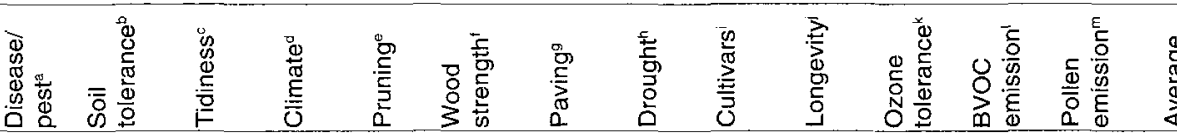

City sector

Juniperus chinensis

Betula pendula

Camellia japonica

Cornus kousa

Uimus parvifolia

2

(2)

政

Sequoia sempervirens

Washingtonia robusta

Pistacia chinensis

Liquidamber styraciflua

Pinus canariensis

$\begin{array}{ll}2 & 2 \\ 2 & 2 \\ 3 & 2 \\ 2 & 2 \\ 2 & 2 \\ 3 & 2 \\ 2 & 1 \\ 2 & 3 \\ 2 & 2 \\ 2 & 2\end{array}$

3
1
3
1
3
3
2
3
3
1

$\begin{array}{lll}3 & 2 & 3 \\ 1 & 2 & 2 \\ 3 & 2 & 3 \\ 3 & 3 & 3 \\ 3 & 3 & 3 \\ 3 & 3 & 3 \\ 3 & 3 & 2 \\ 1 & 3 & 3 \\ 3 & 2 & 1 \\ 3 & 2 & 2\end{array}$

Mean

Suburban sector

Quercus wislizeni

Q. lobata

Morus atba 'Fruitless'

2
3
2
2
1

$\begin{array}{lll}3 & 2 & 3 \\ 2 & 2 & 3 \\ 2 & 2 & 3 \\ 3 & 2 & 3 \\ 2 & 2 & 3\end{array}$

Cupressus sempervirens 'Stricta'

Celtis sinensis

Prunus sargentii

S. gigantea

Ailanthus altissima

Liquidamber styraciflua

$\begin{array}{llll}2 & 3 & 2 & 3 \\ 1 & 3 & 2 & 3 \\ 1 & 2 & 2 & 3 \\ 2 & 3 & 2 & 1 \\ 2 & 2 & 2 & 3\end{array}$

Mean

Rural sector

Albizia julibrissin

Quercus kelloggii

Q. wislizenii

Elaeagnus angustifolia

Q. lobata

Pinus sabiniana

Liquidamber styraciflua

Pinus nigra

Q. douglasii

Ligustrum /ucidum

Mean

Commonly planted today

Sequoia sempervirens

Pistacia chinensis 3

Pyrus calleryana 2

Celtis sinensis

Acer rubrum

Lagerstroemia indica

A. palmatum

Nyssa sylvatica

Quercus rubra

A. buergerianum

$\begin{array}{llll}1 & 3 & 2 & 3 \\ 3 & 3 & 2 & 3 \\ 2 & 3 & 2 & 3 \\ 1 & 2 & 2 & 3 \\ 3 & 2 & 2 & 3 \\ 3 & 2 & 2 & 3 \\ 2 & 2 & 2 & 3 \\ 1 & 2 & 2 & 1 \\ 3 & 3 & 2 & 3 \\ 2 & 2 & 2 & 3\end{array}$

1
3
1
3
3
1
3
3
1
3

$\begin{array}{ll}3 & 2 \\ 2 & 2 \\ 1 & 1 \\ 3 & 3 \\ 2 & 2 \\ 2 & 2 \\ 2 & 3 \\ 3 & 2 \\ 1 & 2 \\ 2 & 1\end{array}$

$\begin{array}{ll}3 & 2 \\ 2 & 2 \\ 2 & 3 \\ 2 & 2 \\ 2 & 3 \\ 1 & 1 \\ 3 & 1 \\ 3 & 2 \\ 2 & 3 \\ 3 & 1\end{array}$

2
1
2
2
2
3
3
2
3
3

$\begin{array}{llll}- & 3 & 3 & 7.7 \\ 3 & - & 1 & 5.2 \\ - & - & 2 & 8.9 \\ - & - & 2 & 7.1 \\ - & - & 2 & 8.3 \\ 3 & 2 & 2 & 7.2 \\ - & 1 & 2 & 6.0 \\ - & 2 & 2 & 8.1 \\ 1 & 1 & 2 & 6.5 \\ - & 2 & 2 & 5.8 \\ & & & 7.1\end{array}$

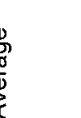

\section{Mean}

$\begin{array}{llllll}3 & 2 & 3 & 3 & 3 & 3 \\ 2 & 3 & 3 & 1 & 3 & 3 \\ 3 & 2 & 1 & 1 & 1 & - \\ 3 & 2 & 3 & 1 & 2 & 2 \\ 2 & 2 & 3 & 1 & 1 & 2 \\ 2 & 2 & 3 & 3 & 2 & 3 \\ 2 & 2 & 1 & 1 & 2 & 3 \\ 3 & 2 & 3 & 3 & 3 & 3 \\ 2 & 2 & 3 & 3 & 3 & 2 \\ 2 & 2 & 3 & 1 & 2 & 3\end{array}$

3
3
2
1
3
2
1
2
3
2

$\begin{array}{ll}1 & 3 \\ 1 & 3 \\ 2 & 2 \\ 1 & 3 \\ 2 & 2 \\ 1 & 3 \\ 2 & 1 \\ 1 & 3 \\ 1 & 2 \\ 3 & 3\end{array}$

$\begin{array}{llll}- & 1 & 1 & 7.1 \\ - & 2 & 1 & 7.4 \\ 1 & 2 & 1 & 5.5 \\ 3 & 2 & 2 & 7.2 \\ - & - & 3 & 7.4 \\ - & 3 & 2 & 6.8 \\ - & - & 3 & 7.5 \\ 3 & 2 & 2 & 6.4 \\ 1 & - & 2 & 5.8 \\ 1 & 1 & 2 & 6.5 \\ & & & 6.8\end{array}$

$1=$ pest $/$ disease sensitive, 2 = resistant, $3=$ free from pests/disease (Gilman et al. 1996); weight $=5$

${ }_{1} 1=$ anything less than $2,2=$ tolerates 2 of 3 textures and occasionally wet or well-drained, or both drainage regimes and 1 of 3 textures, $3=$ tolerates all 3 textures and occasionally wet or well-drained soil (Gilman et al. 1996); weight $=5$.

$c 1=>1$ litter type, $2=1$ litter type, $3=$ no litter (Reimer 1996); weight $=5$.

$1=$ not adapted to Sacramento climate, $2=$ adapted to Sacramento and warmer climates, $3=$ adapted to Sacramento and cooler climates (Reimer 1996); weight $=5$.

${ }^{* 1} 1$ = pruning necessary for strong structure, $2=$ undefined, $3=$ little required (Gilman et al. 1996; Fitch 1996); weight = 3 .

$t_{1}=$ weak wood, 2 = medium, $3=$ strong (Pacific Gas \& Electric 1993); weight $=3$.

$91=$ can form large surface roots, $2=$ occasional problem, $3=$ not a problem (Reimer 1996); weight = 3 .

${ }^{n} 1=$ low drought tolerance, $2=$ medium, $3=$ high (Costello and Jones 1992); weight $=3$.

$i 1=$ no cultivars, $2=1-3,3=>3$ (Gilman et al., 1996); weight $=3$.

$11=$ lifespan $<25 \mathrm{yr}, 2=25-50 \mathrm{yr}, 3>50 \mathrm{yr}$ (Gilman et al. 1996); weight $=1$.

${ }^{k} 1=$ ozone sensitive, $2=$ undefined, $3=$ tolerant (Gilman et al. 1996); weight $=1$.

$11=$ BVOC emission $>10,2=1-10,3<1 \mathrm{~g} / \mathrm{g}$ dry leaf $\mathrm{wt} / \mathrm{hr}$ (Benjamin et al. 1996); weight $=1$.

$m 1=$ high allergenicity, $2=$ moderate, $3=$ low (based on average rankings from 5 surveys returned by local allergy clinics); weight $=1$. 
erences will influence the future urban forest. Factors most likely to trigger change in the composition of Sacramento's urban forest over the next 50 years are described below and serve as a basis for developing a list of trees that merit testing (Table 8).

1. Tree size and ornamental qualities: The trend toward more compact development will continue with the concomitant need for large shade trees along streets and in public spaces, as well as smaller trees for residential yards. Table $8 \mathrm{con}$ tains species with a mix of mature sizes. Also, it contains temperate region cultivars selected in part for their excellent fall color, which will continue to be a highly valued feature in Sacramento. Several taxa with especially attractive flowers are included as well.

2. Water conservation: Installation of water meters and pricing that promotes conservation will result in landscape conversions that reduce water use. Changes in the Sierra snow pack and snow melt associated with changes in global climate could reduce water supplies for landscape irrigation and increase tree moisture stress (Vaux 1991). Tree species that tolerate lawn irrigation as well as drought will fare best during the transition to fewer water-consuming landscapes. Trees that can survive without irrigation after establishment will have higher survival rates in settings (e.g., streets, parks, commercial) where irrigation is periodically discontinued and maintenance is irregular. Trees likely to thrive in Sacramento's Mediterranean climate and proven to be popular in xeric regions of Mexico, Texas, and Arizona are included in Table 8.

3. Maintenance issues: Fruit litter from urban trees is a nuisance that can be minimized through selection of fruitless cultivars (Barker 1986). Similarly, thorns, overly vigorous growth, poor branching structure, invasive roots, and susceptibility to pests and disease are undesirable features of trees that increase maintenance costs. Table 8 contains taxa that are relatively low maintenance.

Urban forest health depends on sound tree selection, continuous replacement planting, and adequate management of existing forest resources. Implementation of a formal program to evaluate promising but untried species, such as those listed in Table 8, is one opportunity for collaborative stewardship aimed at creating a healthier urban forest. However, as the limited suitability analysis suggests, much work is needed to develop better quantitative measures for assessing site conditions, physiological performance, benefits, costs, and human response to trees in the landscape.

\section{Conclusions}

People are the paramount agents of change in urban forest development. By influencing when and how development occurs, selecting tree species to plant, and managing those trees over time, each generation of residents leaves an indelible mark on the urban forest. That human imprint is most evident in our city centers, where trees have been nurtured the longest and impacts of urbanization are most profound. This assertion is supported by the surprisingly similar structure of urban forests in the city sectors of Sacramento and Chicago. In both cities, areas with large, old shade trees and a complex understory provide benefits analogous to those of a climax forest. Rejuvenating these aging forests by extending the longevity of overmature trees and long-term planning to replace removed trees is a primary management issue. In other areas that contain relatively few trees, the focus is on planting and stewardship of well-adapted trees.

This study confirms the importance of urban forest cover in residential areas. In Sacramento, Chicago, and other U.S. cities such as Syracuse New York, Birmingham, Alabama, and Cincinnati and Dayton, Ohio

Table 7. Structural characteristics of tree populations in Sacramento and Chicago.

\begin{tabular}{|c|c|c|c|c|c|c|c|c|}
\hline \multirow[b]{2}{*}{ Structural measure } & \multicolumn{4}{|c|}{ Sacramento } & \multicolumn{4}{|c|}{ Chicago } \\
\hline & City & Suburban & Rural & Region & City & Suburban & Rural & Region \\
\hline Pop. density (person/ha) & 16.7 & 16.4 & 0.6 & 4.4 & 46.1 & 12.4 & 9 & 17.6 \\
\hline Tree canopy cover (\%) & 13 & 15.4 & 5.2 & 7.4 & 11 & 23 & 19 & 19 \\
\hline Tree density (tree/ha) & 73.4 & 63.8 & 9.8 & 23.4 & 68.5 & 169.5 & 171 & 151.7 \\
\hline Basal area $\left(m^{2} / h a\right)$ & 13.4 & 4.5 & 0.9 & 2.6 & 11.8 & 18.7 & 19.2 & 17.6 \\
\hline No. species sampled & & & & 118 & & & & 108 \\
\hline Trees/capita & 4.4 & 3.9 & 15.2 & 5.3 & 1.5 & 13.7 & 19.1 & 8.6 \\
\hline Street trees/capita & 0.29 & - & - & - & 0.15 & 0.37 & 0.25 & 0.25 \\
\hline Off-street/on-street & 14.1 & - & - & - & 8.9 & 36 & 75.9 & 33.5 \\
\hline
\end{tabular}


Table 8. Trees that merit greater planting and performance evaluation in Sacramento (bold indicates available in the nursery trade).

\begin{tabular}{|c|c|c|}
\hline Botanical name & Common name & Remarks ${ }^{a, b}$ \\
\hline Acer grandidentatum & Bigtooth maple & S,D, slow start, Southern origin best \\
\hline A. negundo 'Sensation' & Sensation box elder & $S, D$ \\
\hline $\begin{array}{l}\text { A. saccharinum } \times \text { A. rubrum } \\
\text { 'Autumn Blaze' }\end{array}$ & Autumn Blaze maple & $\begin{array}{l}\text { L,D, hybrid with vigor of silver maple and stronger structure, good } \\
\text { shade tree }\end{array}$ \\
\hline A. truncatum & Purpleblow maple & M,D, purple fall color, cultivar available \\
\hline Cercidium x Desert Museum & $\begin{array}{l}\text { Desert Museum } \\
\text { Paio Verde }\end{array}$ & S,D, thornless, fruitless, yellow flowers, for dry sites \\
\hline Chilopsis linearis & Desert willow & $\begin{array}{l}\mathrm{S}, \mathrm{D} \text {, dark purple flowers, messy pods, other cultivars available, } \\
\text { train when young }\end{array}$ \\
\hline x Chitalpa tashkentensis & Chitalpa & $\begin{array}{l}\text { S,D, needs training when young, long blooming period, no pods, } \\
\text { specimen }\end{array}$ \\
\hline Fraxinus greggi & Littleaf ash & $\mathrm{S}$, Semi-e, slow to $5 \mathrm{~m}$, tough sites \\
\hline F. pennsylvanica 'Patmore' & Patmore ash & $\begin{array}{l}\mathrm{L}, \mathrm{D} \text {, done well in Modesto, good shade tree, susceptible to ash } \\
\text { yellows, whitefly }\end{array}$ \\
\hline Glyptostrobus pensilis & Chinese swamp cypress & $M, D$, lawn tree, good fall color \\
\hline Gymnocladus dioica & Kentucky coffeetree & $\begin{array}{l}M, D \text {, slow starter, good form, sap from wounds and female fruit } \\
\text { pods a problem }\end{array}$ \\
\hline Koelreuteria elegans & Formosan flametree & $S, D$, attractive foliage and fruit, fruit not as messy as other species \\
\hline Pinus patula & Jelecote pine & $L, E$, fast growing, handsome foliage \\
\hline P. oaxacana & Oxacana pine & $L, E$, graceful foliage, rounded crown \\
\hline Prosopis alba 'Colorado' & Colorado mesquite & S,D, thornless and podless, lawns or dry sites \\
\hline Quercus laceyi & Lacey oak & S,D, slow starter, bluish foliage \\
\hline Q. macrocarpa & Bur oak & L,D, good lawn tree, wildlife \\
\hline Q. muehlenbergii & Chinquapin oak & L,D, upright growth, lawns/parks \\
\hline Q. shumardii & Shumard oak & $L, D$, good fall color, soil tolerant \\
\hline Q. virginiana & Southern live oak & $L, E$, tolerant of lawn or dry situations \\
\hline Syringa reticulata 'Ivory Silk' & $\begin{array}{l}\text { Ivory silk Japanese } \\
\text { tree lilac }\end{array}$ & $\begin{array}{l}\text { S,D, straight trunk, vigorous growing, attractive blooms, tough } \\
\text { sites }\end{array}$ \\
\hline Taxodium distichum & Baid cypress & L,D, good lawn tree, soil tolerant \\
\hline T. mucronatum & Montezuma cypress & L,Semi-E, soil tolerant, lawns/parks \\
\hline $\begin{array}{l}\text { Vitex agnus-castus } \\
\text { Xylosma congestum }\end{array}$ & $\begin{array}{l}\text { Chaste tree } \\
\text { Xylosma }\end{array}$ & $\begin{array}{l}S, D \text {, takes tough sites, cultivars available, needs training } \\
S, E \text {, tolerates tough sites, needs training }\end{array}$ \\
\hline
\end{tabular}

${ }^{\mathrm{S} S}=$ small $(<8 \mathrm{~m}$ tall), $M=$ medium $(8-15 \mathrm{~m}), \mathrm{L}=$ large $(>15 \mathrm{~m})$.

${ }^{\mathrm{b}} \mathrm{D}=$ deciduous, Semi-e $=$ semi-evergreen, $E=$ evergreen.

(Rowntree 1984), residential land accounts for nearly half of the total land area. About half of the residential land is covered by impervious building and paving surfaces, and the remainder is pervious. Of the pervious land cover, approximately $40 \%$ is tree/shrub cover and $60 \%$ is grass/soil cover. Considering Sacramento's city and suburban sectors alone, where $90 \%$ of the population resides, about $75 \%$ of all trees, basal area, and leaf surface area occurs on residential land uses.

By describing the structure and sustainability of Sacramento's urban forest, a baseline is created against which future change can be compared. Information on the existing forest's structure was used by a task force in development of the region's first State of the Urban Forest Report 1996 (Sacramento Urban For- est Task Force 1996). The report articulated the task force's shared vision for stewarding a sustainable urban forest. Furthermore, data on forest structure and composition are key elements of modeling studies reported in this journal that estimate the function and value of environmental services produced by the region's 6 million trees. Subsequent analyses of benefits and costs associated with alternative regional urban forest plans could utilize findings of this study. Although results for Sacramento cannot be directly extrapolated to other locations, inventory protocols and structural measures applied here are transferable. Replication of this approach in other regions and resulting comparisons can lead to a more complete understanding of the forests in which we live. 


\section{Literature Cited}

Arnold, C.L., and C.J. Gibbons. 1996. Impervious surface coverage: The emergence of a key environmental indicator. APA Journal. 62:243-258.

Barker, P.A. 1975. Ordinance control of street trees. J. Arboric. $1: 212-216$.

Barker, P.A. 1986. Fruit litter from urban trees. J. Arboric. 12:293-298.

Benjamin, M.T., M. Sudol, L. Bloch, and A.M. Winer. 1996. Low-emitting urban forests: A taxonomic methodology for assigning isoprene and monoterpene emission rates. Atmos. Environ. 30:1437-1452.

Bernhardt, E., and T.J. Swiecki. 1993. The State of Urban Forestry in California-1992. California Department of Forestry and Fire Protection, Sacramento, CA.

Clark, J.R., N.P. Matheny, G. Cross, and V. Wake. 1997. A model of urban forest sustainability. J. Arboric. 23(1): 17-30.

Costello, L.R., and K.S. Jones. 1992. WUCOLS ProjectWater Use Classification of Landscape Species. Univ. Calif. Coop. Ext. Serv., Oakland, CA.

Dawson, J., and M. Khawaja. 1985. Change in street-tree composition of two Urbana, Illinois neighborhoods after fifty years: 1932-1982. J. Arboric. 11:344-348.

Duerksen, C.J., and S. Richman. 1993. Tree Conservation Ordinances. American Planning Association, Chicago, IL.

Gilman, E.F., H.W. Beck, D.G. Watson, P. Fowler, D.L. Weigle, and N.R. Morgan. 1996. Southern Trees. Univ. Fla., Gainesville, FL.

Horie, Y., S. Sidawi, and R. Ellefsen. 1991. Inventory of Leaf Biomass and Emission Factors for Vegetation in the South Coast Air Basin. Air Quality Management Plan.

Katibah, E.F. 1984. A brief history of riparian forests in the Central Valley of California. In Warner R.E. (Ed.). Proceedings of the California Riparian Systems Conference. Univ. Calif. Press, Berkeley, CA.

Kielbaso, J.J., M.N. de Araujo, A.J. de Araujo, and W.N. Cannon. 1993. Monitoring the Growth and Development of Urban Forests in Bowling Green, Ohio and Lincoln, Nebraska. American Forests. Washington, DC.

Levenson, J.B. 1981. The southern-mesic forest of southeastern Wisconsin: Species composition and community structure. Contributions in Biology and Geology, Number 41. Milwaukee Public Museum, Milwaukee, WI.

McBride, J., and D. Jacobs. 1976. Urban forest development: A case study, Menlo Park, California. Urb. Ecol. 2:1-14.

McBride, J., and D. Jacobs. 1986. Presettlement forest structure as a factor in urban forest development. Urb. Ecol. 9:245-266.

McDonnell, M.J., S.T.A. Pickett, and R.V. Pouyat. 1993. The application of the ecological gradient paradigm to the study of urban effects, pp 175-189. In McDonnell M.J., and S.T.A. Pickett (Eds.). Humans as Components of Ecosystems: Subtle Human Effects and the Ecology of Populated Areas. Springer-Verlag, New York.

McPherson, E.G., and R.A. Haip. 1989. Emerging desert landscape in Tucson. Geogr. Rev. 79:435-449.

McPherson, E.G., D.J. Nowak, and R.A. Rowntree. (Eds.) 1994. Chicago's Urban Forest Ecosystem: Results of the Chicago Urban Forest Climate Project. USDA For. Serv.
Northeast. For. Exp. Sta. Gen. Tech. Rpt. NE-186. Radnor, PA.

McPherson, E.G., D.J. Nowak, P.L. Sacamano, S.E. Prichard, and E.M. Makara. 1993. Chicago's Evolving Urban Forest: Initial Report of the Chicago Urban Forest Climate Project. Northeast For. Exp. Sta.Gen. Tech. Rpt. NE-186. Radnor, PA.

McPherson, E.G., and R.A. Rowntree. 1989. Using structural measures to compare twenty-two U.S. street tree populations. Landscape J. 8:13-23.

Miller, R.H., and R.W. Miller. 1991. Planting survival of selected street tree taxa. J. Arboric. 17:185-191.

Miller, R.W. 1997. Urban Forestry: Planning and Managing Urban Greenspaces. Prentice-Hall, Upper Saddle River, NJ.

Myrup, L.O., and D.L. Morgan. 1972. Numerical Model of the Urban Atmosphere: The City-Surface Interface. Contributions in Atmospheric Science No. 4. Univ. Calif., Davis, CA.

Nowak, D.J. 1993a. Compensatory value of an urban forest: An application of the tree-value formula. J. Arboric. 19:173-177.

Nowak, D.J. 1993b. Historical vegetation change in Oakland and its implications for urban forest management. J. Arboric. 19:313-319.

Nowak, D.J. 1994. Urban forest structure: The state of Chicago's urban forest, pp 3-18. In McPherson E.G., D.J. Nowak, and R.A. Rowntree (Eds.). Chicago's Urban Forest Ecosystem: Results of the Chicago Urban Forest Climate Project. USDA For. Serv. Northeast. For. Exp. Sta. Gen. Tech. Rpt. NE-186. Radnor, PA.

Nowak, D.J., J. McBride, and R.A. Beatty, 1990. Newly planted street tree growth and mortality. J. Arboric. 16:124-129.

Pacific Gas \& Electric. 1994. TreeFinder: A Shade Tree User Manual. PG\&E, San Francisco, CA.

Peper, P.J., and E.G. McPherson. 1998. Comparison of five methods for estimating leaf area index of open-grown deciduous trees. J. Arboric. 24(2):97-110.

Polanin, N. 1991. Removal history and longevity of two street tree species in Jersey City, New Jersey. J. Arboric. 17:303-305.

Reimer, J. 1997. SelecTree: A Tree Selection System. University of California. San Luis Obispo, CA.

Richards, N.A. 1982/83. Diversity and stability in a street tree population. Urb. Ecol. 7:159-171.

Richards, N.A. 1993. Optimum stocking of urban trees. J. Arbor. 18:64-68.

Rowntree, R.A. 1984. Forest canopy cover and land use in four eastern United States Cities. Urb. Ecol. 8:55-67.

Rowntree, R., D. Nowak, E. Kerkmann, and M. Davis. In press. Urban Forest Canopy Cover for 21 California Cities. USDA For. Serv. Pac. Southw. Res. Sta., Albany, CA.

Sacramento Area Council of Governments. 1995. SACOG 1994 Housing Module. Sacramento Area Council of Governments, Sacramento, CA.

Sacramento Urban Forest Task Force. 1996. State of the Urban Forest Report 1996. City of Sacramento/ Sacramento Tree Foundation, Sacramento, CA.

Sampson, R.N., G.A. Moll, and J.J. Kielbaso. 1992. Opportunities to increase urban forests and the potential 
impacts on carbon storage and conservation, pp 51-72. In Sampson R.N., and D. Hair (Eds.). Forests and Global Change: Opportunities for Increasing Forest Cover. American Forests, Washington, DC.

Sommer, R., H. Guenther, and P. Barker. 1990. Surveying householder response to street trees. Landscape J. 9:7985.

Tschantz, B.A., and P.L. Sacamano. 1994. Municipal Tree Management in the United States. International Society of Arboriculture. Savoy, IL.

Toro Company. 1966. Rainfall-evapotranspiration data, United States and Canada. Toro Company, Minneapolis, MN.

Tugel, A.J. 1993. Soil Survey of Sacramento County, California. USDA SCS. Washington, DC.

Vaux, H.J. 1991. Global climate change and California's water resources, pp 69-96. In Knox J.B., and A.F. Scheuring (Eds.). Global climate change and California: Potential impacts and responses. Univ. Calif. Press, Berkeley, CA.

Wolfe Mason Associates. 1992. Sacramento Urban Forest Management Plan. City of Sacramento Parks and Community Services, Sacramento, CA.

\section{Appendix A}

The formulas for estimating the total number of trees and the standard error (se) for photo-land use / belonging to true-land use $k$ for a SubRAD $r$ are

$$
\begin{gathered}
y_{l k}=\frac{p_{l k}}{n_{l k}} \sum_{r=1}^{R_{s}} \sum_{i=1}^{n_{r l k}} \frac{y_{r l k i}}{z_{l r i}} \\
s e\left(y_{l k}\right)=\sqrt{\frac{1}{n_{l k}\left(n_{l k}-1\right)} \sum_{r=1}^{R_{s}} \sum_{i=1}^{n_{r l k}}\left(\frac{y_{r l k i}}{z_{r l k i}}-y_{l k}\right)^{2}}
\end{gathered}
$$

where

$y_{1 k}=$ estimated total number of trees in sector $s$ for photo-land use / belonging to true-land use $k$

$p_{l k}=$ estimated proportion of plots on photo-land use I with true-land use $k$

$n_{1 k}=$ total number of sampled dots for photo-land use I belonging to true-land use $k$

$R_{s}=$ number of SubRADs in sector $s$

$n_{r k}=$ number of sample dots (plots) in photo-land use $I$ belonging to true-land use $k$ in SubRAD $r$

$z_{r t i}=$ probability of selecting dot $/$ for photo-land use $I$, in SubRAD $r$

$y_{r k i}=$ number of measured trees in plot $/$ for photo-land use $/$ belonging to true-land use $k$ in SubRAD $r$

$n_{r l k}=$ number of sample dots (plots) in photo-land use I belonging to true-land use $k$ in SubRAD $r$

$z_{r k \mathrm{i}}=$ probability of selecting dot $/$ belonging to trueland use $k$ given that dot $/$ is on photo-land use $I$, in SubRAD $r$.
The se $\left(y_{i k}\right)$ does not account for the variability of $p_{l k^{\prime}}$ an estimate of the true proportion of plots on photo-land use / with true-land use $k, p_{i k}$ was calculated using the data in this study. The estimation of such parameters as tree density, basal area, leaf area density, and number of trees in tree condition classes was also done using the probability of selection $z_{r k k^{*}}$.

\section{Appendix B}

To estimate the number of trees in a SubRAD by true-land use, it is assumed that tree cover characteristics are uniform for the same land use within a sector. The number of trees $\left(R_{y r k}\right)$ in SubRAD $r$ for true-land use $k$ and its standard error (se) are

$$
\begin{gathered}
R y_{r k}=\frac{T S_{r k}}{S A_{k}} T y_{k} \\
s e\left(R y_{r k}\right)=\frac{T S_{r k}}{S A_{k}} \operatorname{se}\left(T y_{k}\right)
\end{gathered}
$$

where

$$
\begin{aligned}
& T S_{r k}=\text { area of true-land use } k \text { in SubRAD } r \\
& S A_{k}=\text { area of true-land use } k \text { in sector } s \\
& T y_{k}=\text { estimate of the total number of trees in plots } \\
& \text { with true land use } k \text { for the entire sector } s \text {. }
\end{aligned}
$$

and se $\left(T y_{k}\right)$ is obtained using se $\left(y_{l k}\right)$ 's for each 1 .

Additional information regarding the development of formulas for estimating parameters of interest is available upon request.

Acknowledgements. I am indebted to the following individuals who assisted with data collection: Vance Howard, Richard Bagaoisan, Melissa Kaufman, Tin Wah Wong, Nina Luttinger, Uma Ramakrishnan, Katherine McGuinn, Linda Roberson, and Ali Griffith. Ellen Zygory and Warren Roberts (both at the UC-Davis Arboretum) provided invaluable assistance with plant identification and assessment of tree species suitability. Sylvia Mori (US Forest Service) provided helpful statistical consultation. Andrew Hertz (formerly U.S. Forest Service) managed the database and produced maps. Drs. Alison Berry, Jim Harding, and Dave Burger (UC-Davis Department of Environmental Horticulture) provided additional assistance throughout the course of the study. Acquisition of aerial photography, demographic, and geographic information was made possible by Craig Crouch and Rick Stassi (County of Sacramento), Dennis Ybarra (City of Sacramento), and Robert Faseler and Ken Gebert (Sacramento Area Council of Governments). I received valuable comments on earlier versions of this manuscript from Russell Beatty (UC-Berkeley), Dr. Jim Clark (HortScience Inc.), Drs. Rowan Rowntree and Phil Barker (US Forest Service), Marty Hughes (County of Sacramento), Martin Fitch (City Tree Services Division), Ray Tretheway (Sacramento Tree Foundation), Ron Gass (Mountain States Nursery, Phoenix), Keith Warren (Schmidt \& Son, Boring, OR), and Dr. Richard Harris (for- 
merly UC-Davis). Finally, my colleagues Dr. Jim Simpson, and Paula Peper, Klaus Scott, and Qingfu Xiao were especially helpful in the conduct and review of this study.

\section{Pacific Southwest Research Station \\ USDA Forest Service \\ c/o Department of Environmental Horticulture \\ University of California \\ Davis, CA 95616}

Résumé. La forêt urbaine du comté de Sacramento compte environ 6 millions d'arbres. La densité en arbres et la surface terrière décroissent en fonction d'un gradient urbain/rural, soit de la zone urbaine (73 arbres/ha, $13,4 \mathrm{~m} \leq 1$ ha), en passant par la banlieue (64 arbres/ha, $4,5 \mathrm{~m} \leq / \mathrm{ha}$ ), à la zone rurale (10 arbres/ha, $0,9 \mathrm{~ms} / \mathrm{ha}$ ). A l'intérieur des zones urbaine et péri-urbaine, là où $90 \%$ des résidents vivent, environ $75 \%$ du nombre total d'arbres, de la surface terrière et du ratio de recouvrement de cime se retrouvent en terrains résidentiels. Dans l'ensemble, la forêt urbaine de Sacramento est bien soutenue. Soixante-dix pourcents des arbres sont en bonne ou excellente condition, la population est bien distribuée dans les classes d'âges et d'espèces, et la plupart des espèces sont celles qui conviennent raisonnablement aux conditions locales de milieu. Les facteurs qui ont provoqué des changements dans la forêt urbaine de Sacramento au cours des 50 dernières années sont enregistrés et les espèces ayant des chances de surmonter ces conditions sont enregistrées pour de futurs plantations et essais. Une comparaison du recouvrement de cime, de la densité et de la surface terrière en arbres des différents secteurs de Sacramento et de ceux de Chicago en Illinois a permis de découvrir de surprenantes similarités. Cependant, à Sacramento, les valeurs de ces indicateurs diminuent en fonction du gradient urbain/rural alors qu'à Chicago ils augmentent.

Zusammenfassung. Die Stadtforste im Bezirk von Sacramento enthalten ca. 6 Millionen Bäume. Die Baumdichte und deren basale Fläche nehmen entlang eines Gradienten von der Stadt (73 Bäume/ha, 13,4 $\mathrm{m}^{2} / \mathrm{ha}$ ) über die
Außenbezirke (64 Bäume/ha, 4,5 $\mathrm{m}^{2} / \mathrm{ha}$ ) bis zum ländlichen Raum (10 Bäume/ha, $0,9 \mathrm{~m}^{2} / \mathrm{ha}$ ) stetig ab. Innerhalb der Stadt und Stadtrandgebiete, wo $90 \%$ aller Bewohner leben, befinden sich ca. $75 \%$ aller Bäume auf bebauter Fläche. Im ganzen sind die Forste von Sacramento relativ selbsterhaltend. $70 \%$ dieser Bäume sind in einem ausgezeichteten Zustand. Die Population ist bezüglich des Baumalters und der Artenverteilung ausgewogen und die am häufigsten vorhandenen Baumarten sind gut verteilt. Hier werden Faktoren gennant, die geeignet sind, die Forste von Sacramento über die kommenden 50 Jahre zu verändern. Ferner werden Arten aufgelistet, die das Potential haben, in diese Konditionen einzudringen. Ein Vergleich der Kronentraufe, Kronendichte und der Basisfläche der Bäume im Stadtbereich von Sacramento, CA und Chicago, IL deckte erstaunliche Übereinstimmung auf. Dennoch nehmen diese Werte in Sacramento entlang eines Stadt-Land-Gradienten ab und Chicago nehmen sie zu.

Resumen. El bosque urbano del Condado de Sacramento tiene aproximadamente seis millones de árboles. La densidad de árboles y el área basal disminuyen en un gradiente urbano-rural de los sectores Ciudad (73 árboles/ ha, $13.4 \mathrm{~m}^{2} / \mathrm{ha}$ ), Suburbano (64 árboles $/ \mathrm{ha}, 4.5 \mathrm{~m}^{2} / \mathrm{ha}$ ), a Rural (10 árboles/ha, $0.9 \mathrm{~m}^{2} / \mathrm{ha}$ ). Dentro de los sectores Ciudad y Suburbano, donde vive el $90 \%$ de los residentes, cerca del $75 \%$ del número total de árboles, área basal y área foliar, ocurre en terrenos residenciales. Sobretodo, el bosque urbano de Sacramento es relativamente sustentable. EI setenta por ciento de los árboles están en excelente condición, la población está bien distribuida por edad y especies, y la mayoría de las especies están razonablemente bien acondicionadas para las condiciones locales. Se describen los factores más probables para disparar el cambio en el bosque urbano de Sacramento durante los próximos 50 años y las especies con potencial de sobrevivir en esas condiciones son listadas para futura planeación y evaluación. Una comparación de cobertura del dosel, densidad, y área basal de los árboles en los sectores Ciudad de Sacramento y Chicago, IL, revela similitudes sorprendentes. Sin embargo, en Sacramento estos valores disminuyen a lo largo del gradiente urbano-rural y en Chicago aumentan. 